\title{
THE ARRIVAL MOTIF OF MALACHI'S ESCHATOLOGICAL FIGURES' IN THE GOSPEL OF LUKE
}

\author{
Paul B. Lee \\ University of Pretoria
}

\section{ABSTRACT}

The writer argues that Luke uses Malachi's motif of eschatological figures as is clear from the literary and thematic structure of the Gospel of Luke. The Lord's messenger and הָָָדון (the messenger of the covenant) are identified as John the Baptist and Jesus respectively, and their missions are fulfilled in Luke. The prophecy of sudden coming of הָָָד to his temple is fulfilled in Jesus' three visits to the temple. The so-called Travel Narrative in Luke echoes idea of "the way of the Lord" in Malachi; the motif of the way of the Lord has thematically a long history in the OT. The concept of the way of the Lord in Exodus and Isaiah is reused in Malachi, and is theologically expanded in its meaning in Luke. The Gospel of Luke can be seen in the perspective of motif of the way of the Lord: the preparation of the Lord's way (1:1-4:13); the presentation of the Lord's way (4:14-19:46), and the perfection of the Lord's way (19:47-24:53).

\section{Introduction}

The significant role that the Book of Malachi plays in the NT is overlooked frequently, but, in fact, many key themes in Malachi occur in the Gospel of Luke (Blomberg 1990:99; Brooks 1987:31). ${ }^{2}$ Malachi's greatest theological motifs or themes used by Luke are found in Malachi 3:1 and 4:5-6. Though Malachi 3:1 is a short sentence, it has abundant theological motifs. The identity and mission of YHWH's messenger as his forerunner, the identity of הָאָדון (the Lord) and the identity of the messenger of the covenant are main issues. In addition, the nature of the covenant in Malachi 3:1, the significance of the advent of הָָָ to his temple, and the relationship between Malachi 3:1 and Malachi 3:2-5 are also important themes. Finally, Malachi 4:5-6 [English version] ought to be discussed with Malachi 3:1 which explains the identity and role of YHWH's messenger. 
Since "the OT has a valid and strong contribution to make to the ongoing theology found in the NT" (Kaiser 1985:151), Malachi also seems to make a significant contribution to the theology of Luke. This article will mainly attempt to demonstrate that Malachi's eschatological figures' arrival motif is used in the Gospel of Luke and to show how the motif influences the Gospel.

\section{The Arrival of Malachi's Eschatological Figures ${ }^{3}$}

\subsection{Luke 7:27}

Luke 7:27 is embedded in the large unit of Luke 7:18-35-which consists of three subunits dealing with Jesus' and John the Baptist's identities. The first subunit, Luke 7:18-23, handles John's question about Jesus' identity and his answer. John's question (7:19-20) through his disciples is, "Are you the Coming One, or should we expect

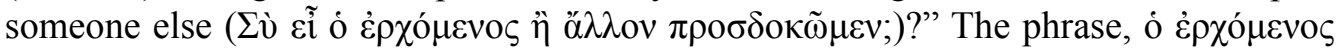
(the Coming One), must be a messianic title, because in Luke 3:15-6 the "Coming One" refers to Messiah. The "Coming One" throughout the Gospel of Luke basically refers to "an eschatological and messianic figure (Luke 3:15-8; 7:22-3; 19:38) [Bock 1996:30]." Luke uses the idea of the "Coming One" at least in two ways. Firstly, Jesus as the "Coming One" will bring the final judgment as well as God's salvation (Luke 3:16-7). Secondly, Jesus is also depicted as the Davidic messianic king in Luke (Kingsbury 1991:57-9), supported by the account of the greetings of Jesus' disciples when He enters the city of Jerusalem (19:38a).

Luke uses the same Greek word $\pi \rho 0 \sigma \delta$ oкó $\omega$ (anticipate) in both Luke 3:15 and 7:19-20. The people of Israel are "anticipating" Messiah, which forced John to clarify that he himself is not the Christ. This reflects the meaning of the word used in Malachi; according to Malachi 3:1, הָָָזדון/the messenger of the covenant ${ }^{4}$ was the one who the people of Israel during Malachi's day were seeking (שִ (צפח, $\theta \dot{\lambda} \lambda \omega)$. In other words, הָָָדון was the Lord who they were earnestly anticipating. The combination of the two words may be equivalent to the Greek word $\pi \rho 0 \sigma \delta$ oкá $\omega$ ("expectantly anticipate") which Luke uses. In Luke's perspective, then, the "Coming One" who they are expectantly waiting for is none other than the Messiah.

Luke in 3:16 shows John's ministry as playing a role of preparing the way for Jesus' ministry (Bock 1996:320). He refers to Jesus' title, "the Lord," ${ }^{5}$ in the story of Jesus' response to John's inquiries ("Are you the one who was to come, or should we expect someone else?"). His answer to John is indirect, but his reply is messianic; Jesus' answer implies, "Yes, I am the 'Coming One,' the Messiah" (Bock 1996:668-9). John, according to Jesus, is called "the greatest" of those born among women, which is reminiscent of Luke 1:15 ("He will be great before the Lord").

The most significant change that Luke makes is the shift in pronoun when Jesus

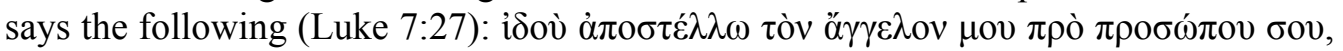

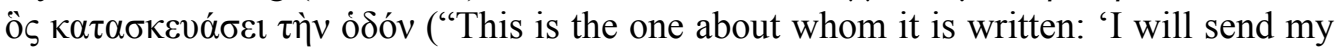


messenger ahead of you, who will prepare your way before you"'). This verse might not draw on Exodus 23:20 ("See, I will send a messenger ahead of you to guard you along the way and to bring you to the place I have prepared"), rather, on Malachi 3:1 for two reasons: first, Malachi 3:1 is itself a reformulated blend of the Exodus text and Isaiah 40:3 ("A voice of one calling: 'in the desert prepare the way for the Lord; make straight in the wilderness a highway for our God""). Second, Exodus 23:20 is not an eschatological prophecy that can be directly fulfilled in Luke 7:27. Since the

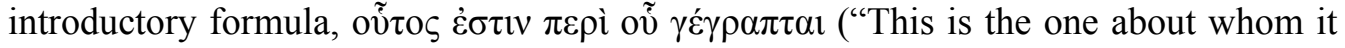
is written"), is a kind of prophecy-fulfillment form, it supports the idea that Luke 7:27 quotes from or refers to Malachi, and that tòv ö $\gamma \gamma \varepsilon \lambda \mathrm{ov} \mu \mathrm{ov}$ ("my messenger") is a reference to John the Baptist. There is already a wide agreement that tòv á $\gamma \gamma \varepsilon \lambda o v ~ \mu o v$ ("my messenger") refers to John the Baptist. ${ }^{6}$

The second-person pronoun oov (changed from Malachi) is understood in two ways. First, it is admitted that the pronoun oov refers to Jesus. Malachi 3:1 contains three figures:

- the speaker/YHWH,

- his forerunner/his messenger who will prepare a way before YHWH, and

-

Luke explicitly identifies John the Baptist as God's forerunner, and also distinguishes between YHWH the speaker and הָָָדון in Malachi 3:1 so that he identifies Jesus as In Malachi 3:1 YHWH promises that He will send his messenger who will prepare a way before Him. Even though He does not identify the one for whom the way is prepared, He implies that the way is his (YHWH's) way, because He announces that the way will be prepared before Him. The preparation of his way is for his coming. However, in Malachi 3:1 and following, God promises two distinct comings of two different characters. After YHWH's way is prepared, first, הָָָזדון/the messenger of the covenant will come (Malachi 3:1-4), and then YHWH will come (Malachi 3:5). The purposes of their comings are different; הזָָדון (the messenger of the covenant) will come for salvation, but YHWH will come for judgment against the wicked. Malachi's Elijah (YHWH's forerunner) prepares for the way of הָזָאדון whose coming is for salvation. Identifying himself as Malachi $3: 1$, Jesus uses the changed pronoun, or deliberately changes the pronoun, to properly apply Malachi's prophecy to Himself. Thus the pronoun change is natural and must take place. The pronoun shift verifies that Luke's (and Jesus') understanding of Malachi's prophecy is proper and right. When Jesus reads and explains Isaiah 61:1-2 in a synagogue of his hometown, Nazareth, He deliberately omits the line in Isaiah 61:2 where God's

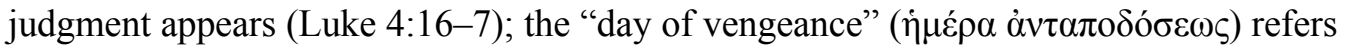
to God's judgment. Luke also underlines Jesus' intention in regard to the omission of the next passage: "Luke's two stage eschatology for Jesus - salvation now, judgment in the future" (Nolland 1989:198). Therefore, the pronoun change in Luke 7:27 also accords with Lukan two-step eschatology. 
Secondly, the referent for oov (your) may be Israel in the Lukan text (Nolland 1989:337, 97). The fact that the pronoun $\sigma 0 v$, as a collective singular, is a reference to the people or the nation of Israel is well explained in the following:

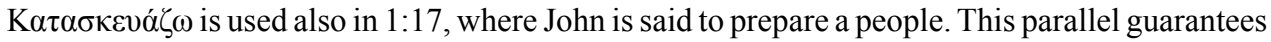
that the reference is to the people. Although John works for God and goes before the Messiah, he also prepares the people for Messiah's coming ... . The prophet of Malachi 3 is compared to the protection that God gave his people by leading them through the wilderness. To respond to John is to be prepared for God's coming in Messiah and to be protected (Bock 1996:674).

The task of YHWH's messenger is to lead Israel out of her disobedient condition and to restore the covenant relationship. His mission is to turn many from their sins - the very ministry of John $(1: 15-7 ; 76-9)$. Therefore, it can be argued that Luke is presenting the fulfilment of Malachi's eschatological figures' arrival in Luke 7:27.

\subsection{Luke 3:4-6}

Luke 3:1-20 describes the preparatory ministry of John the Baptist for the Lord. The main issue here is that Isaiah $40: 3-5$ is quoted in Luke 3:4-6, and that Isaiah 40:3 is known as a classic expression of God's salvation for Israel from Babylonian captivity. As it is argued that "the important point about correspondence in history is that the text is not used up by a single event" (Snodgrass 2007:38), Malachi 3:1 reuses a theme in Isaiah 40:3 and borrows a similar terminology to describe God's promise of future salvation for his people (Nolland 1989:38) in an eschatological context (Pao and Schnabel 2007:276); it is a renewed and expanded theme of Malachi 3-4. The role of Malachi's Elijah is found in its typological prophetic fulfillment form in John's ministry.

\section{The Lord's Arrival to his Temple in Malachi and Jesus' Visit to the Temple in Luke}

Luke frequently mentions the word кúpios (Lord). The Lord usually refers to God (1:15, 17). Luke, however, seems to suggest to the reader that the title "the Lord" may be used as a double reference. Especially in the birth narrative the Lord may denote Jesus $(1: 43 ; 2: 11)$, or God the Father, or both. The ambiguous mixed reference may be Luke's intentional expression to make Jesus equal with God. In the infancy narrative Luke implicitly and explicitly describes Jesus as Lord. In Luke 2:11 he depicts Jesus as the Lord. Just as Malachi identifies the messenger of the covenant/Messiah with הָָָדון Luke presents Jesus as both the Messiah and Lord. Luke presents that the Lord comes to his temple according to the prophecy of Malachi.

\subsection{Temple Emphasis}

The importance of the temple and Jerusalem is emphasised in the Gospel of Luke (Chance 1988:2). For example, the Gospel of Luke forms a chiastic inclusio by the 
scenes of the temple: true temple worship (Luke 1) and true worship of Jesus' disciples in the temple (Luke 24). Especially Luke gives a prominent role to the temple in Luke 1 and 2; three episodes occur in the temple. Unlike Matthew, Luke, by placing Jesus' trip to the top of the temple in the temptation incident as the last and third temptation, seems to place his emphasis on the Jerusalem temple. The order of the incidents cannot be coincidental with the prophecy of Malachi's eschatological figure's arrival. Luke's emphasis on the temple and Jesus' coming to the temple discloses that the Gospel of Luke is related to the Book of Malachi. The fulfilment essentially has an eschatological element in its nature (Chance 1988:2; Hutcheon 2000:47).

\subsubsection{Luke 2:21-397}

Jesus' parents are law-abiding people so that they fulfill the law of purification by going to Jerusalem with Jesus to present Him to the Lord. At the temple, the infant Jesus is presented to the Lord according to the Law of Moses. In the temple, Jesus is recognised as Messiah by a few true believers. When Jesus is brought into the temple, a righteous and devout man Simeon, being led by the Holy Spirit, gives testimony to Jesus' identity.

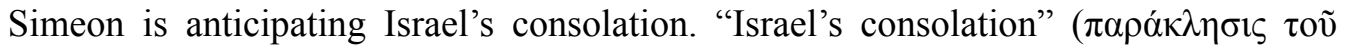

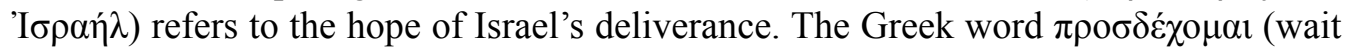
for, anticipate) is used in 2:25 and in 2:38 (cf. 12:36; 23:51), and its meaning is similar

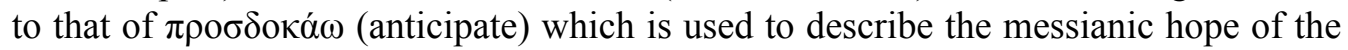
people who are waiting for the "Coming One" (3:15; 7:19-20). God's promise by the Holy Spirit to Simeon that he would not die without seeing the Messiah surely caused him to anticipate Messiah. Luke here links the coming of Messiah with Israel's consolation. At the temple Jesus is again recognised as Messiah by a prophetess, Anna. According to Luke 2:38, Anna speaks about Jesus to "all who are anticipating the

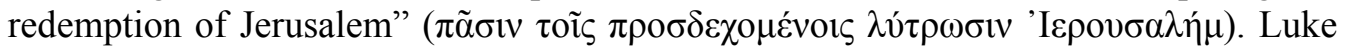
implies that Jesus is closely related to Jerusalem's redemption ( $\left.\lambda v^{\tau} \rho \omega \sigma \mathrm{s} \varsigma^{\prime} I \varepsilon \rho 0 v \sigma \alpha \lambda \eta \dot{\mu}\right)$. Luke already adumbrated to the reader through Zechariah's praise that God's salvation activity was associated with the birth of Jesus Christ (Luke 1:68); "He [God] has come

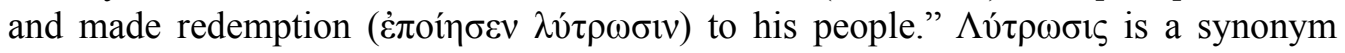
for "salvation" used by Zechariah and Anna (Steyn 2005:72). This also emphasizes "Jerusalem as the centre of God's eschatological salvation" (cf. 1:17, 19, 76; 2:25, 3031; 3:4-6) [Pao 2007:274]. The incident of Jesus in the temple demonstrates that Jesus is superior to John the Baptist (Bock 1996:230). Since "the major attention in Luke 1-2 belongs to Jesus" (Bock 1996:230), John is presented as a forerunner of the Lord and Jesus is declared as Messiah. Luke interprets Jesus' coming to the temple in Luke 2 as a fulfilment of Malachi 3:1-2 as in the following argument:

The Malachi 3:1-2 passage goes on to promise: "The Lord whom you seek will suddenly come to his temple ... Who can endure the day of his coming?" After the description of John the Baptist in Luke 1, is it accidental that in Luke 2 the child Jesus who has been hailed as Lord (2:11) comes to the temple to be recognized by Simeon who was "waiting for the consolation of Israel?" And 
Simeon predicts in 2:34-35 that this coming of the Lord to the temple is the beginning of his role as a sign of discrimination so that many will fall—or, in the words of Malachi, many will not endure the day of his coming" (Brown 1979:445).

In short, a major purpose of the account of the baby Jesus' visit to the temple may also be found in the following statements:

\begin{abstract}
One must start by asking what Lucan purposes (either narrative or theological) were served by Luke's having the forty-day old infant Jesus being brought into the temple by his parents. Luke's ostensible reason - to fulfill the Jewish law of purification for women after childbirth (Lev 12:6-8), and the law of redemption of the firstborn (Ex 13:2, 13) - is contradicted by his statement that Jesus' parents "brought him up to Jerusalem to present him to the Lord" (v. 22), something not mandated by the Law of Moses. More likely, in ... this narrative, Luke had in mind prophecies such as Malachi 3:1a ("I send my messenger to prepare the way before me [a prophecy of John the Baptist], and the Lord whom you seek will suddenly come to his temple") [Hutcheon 2007:12].
\end{abstract}

Messiah Jesus' coming to the temple was an unexpected and sudden visit to the people who were seeking the Lord. The prophecy of Malachi 3:1 was fulfiled literally by Jesus' sudden visit to the temple according to Luke.

\title{
3.1.2 Luke 2:41-50
}

Luke 2:41-50 is the account of Jesus' second visit to the Jerusalem temple. Just as in Jesus' first journey to Jerusalem (2:22-39), the final destination of this second travel to Jerusalem is the temple, because the purpose of the trip is the Feast of the Passover (2:41). The meaning of Luke 2:49 has been debated, but it is the key verse to understand the episode. Luke seems to intentionally make a sharp contrast by placing Mary's words

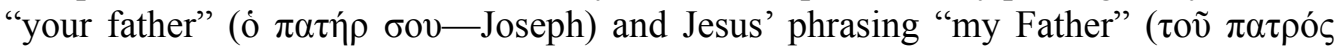
Hov - God the Father). Some ideas about Jesus' identity may be traced from Jesus' response to Mary's question as follows: 1) the temple as the dwelling place of God is also the place where the Son of God is found; 2) so people should seek Him in the temple; 3) Jesus' statement, "Did you not know that I must be in my Father's house?" indicates that Jesus Himself acknowledges that He is the Son of God; (4) therefore, since Jesus is the Son of God the Father, his earthly father and mother should seek Him in the temple if they want to find Him. Jesus' identity reveals the place where He is found. Where one is found is determined by who he is (Kilgallen 1985:557). Jesus says, "I must ( $\delta \varepsilon \tilde{\imath})$ be in my Father's house." The Greek word $\delta \varepsilon \tilde{\imath}^{8}$ is a key Lukan term "used strategically in the Gospel where elements of Jesus' mission are set forth" (Bock 1996:269). The so-called divine $\delta \varepsilon \tilde{i}$ discloses Jesus' relationship to the Father and his mission as well. If one follows the logic of Jesus' statement, he may recognise that Jesus is the Son of God. Joseph and Mary must seek to find Jesus in the temple because $\mathrm{He}$ is the Lord whom his people should seek in the temple. Terms such as "temple" and "seek" remind the reader of Malachi 3:1. Luke 1-2 certainly alludes to Malachi's 
prophecy regarding the Lord's visit to his temple and his purification of the sons of Levi (Malachi 3) [Laurentin 1966:90-1]. However, it cannot be merely an allusion to Malachi 3, because Malachi 3 is definitely intended as a prophecy. The statement of the boy Jesus at the temple, "Didn't you know that I must be in the things of my Father

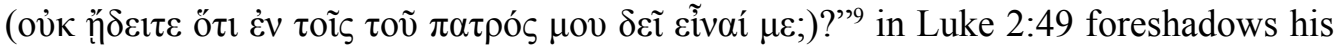
future mission. In other words, the incident of Jesus at the temple hints that He will come back and purify the temple of God (Laurentin 1966:48-50). Luke 2:41-50 surely prefigures Jesus as a teacher (Kilgallen 1985:553-9) and foretells Jesus' public teaching ministry in the temple (Kilgallen 1985:553-59). Moreover, this passage is the "true beginning" of Jesus' public ministry because Jesus listens to the teachers of the law and asks them questions (Hutcheon 2000:14). This incident also previews Jesus' third journey to Jerusalem (Hutcheon 2000:14). There must be a strong thematic connection between Malachi 3-4 and Luke 2 (Van der Waal 1973:53-4). The correlation of the Lord's sudden coming to his temple in Malachi 3:1 and Jesus' visit to the temple in Luke 2 can be argued as follows:

When we read in Luke 2 about the presentation of Jesus in the temple, we should not lose sight of Malachi 3 and 4: the Lord is coming to the temple! In the temple (2:27) Simeon clearly states that Jesus is destined to be a fall and resurrection of many in Israel (2:34) and to be a sign which shall be spoken against (cf. Isaiah 8:14). These words constitute the theme of the Gospel of Luke ... . In the story of the twelve year-old Jesus we again see how Malachi 3:1 is fulfilled: the Lord is coming to the temple, just in the Passover time (Van der Waal 1973:53-4).

Luke 2:41-50 is clearly a fulfilment of Malachi 3:1-4. There is no one but Jesus who can be called "the Lord" (דָזָז).

\subsubsection{Luke 19:45-21:38}

Luke 19:45-21:38 describes Jesus' third visit to the temple and his ministry there. Thus the section may be divided into two major units by Jesus' two significant activities, though the first unit is much shorter than the second one. The first unit, 19:45-6, depicts Jesus' visit to the temple and his symbolic act in the temple; the second unit, 19:47$21: 38$, records Jesus' teaching ministry at the temple.

\subsubsection{Luke 19:45-6}

Jesus' act in the temple has been understood in various ways (Nolland 1993:935-6), but the account may be viewed with one or both of the following explanations: 1) Jesus consciously demonstrates the symbolic act to fulfil Malachi 3:1-2, because $\mathrm{He}$ is aware of Malachi's prophecy and knows that He is הָזָז and 2) Jesus' activity is symbolically prophetic (Nolland 1993:935-6). Jesus' protest in the temple may be understood in the perspective of Malachi 1:10 (Nolland 1993:938). It can be argued that Jesus performs the symbolic activity to encourage the people who are coming to the temple to offer genuine and acceptable worship, and to live a godly life. In 
addition, Jesus' prophetic symbolic act is 1) to bring about Israel's spiritual restoration by their repentance of their sins and return to the Lord, or 2) to symbolise God's judgment which results in the future destruction of the temple (Nolland 1993:936). Malachi 3:1-4 functions as a covenant lawsuit which requires purification of the Levites to offer pure offerings (O'Brien 1990:73-5). Jesus' act in the temple may be regarded as covenant enforcement, and Jesus may be viewed as the covenant agent. His purification act foreshadows God's final judgment. Thus Jesus' act in the temple is regarded as the fulfilment of the prophecy of Malachi 3:1 (Dawsey 1984:158-9. Cf. Evans 1989:252). Jesus' cleansing act may be also considered as "a means of taking possession" of the temple (Conzelmann 1960:77-8). It means that Jesus reoccupied it or that He declared it as his own through his activity. Jesus' purification of the temple is to prepare Jerusalem and the temple for the coming of the kingdom of God (Hiers 1971:82-90). This interpretation may be well understood in light of Malachi 3:2-4, because Malachi certainly foretells the restoration of the temple and the Davidic kingdom. As a Gentile, Luke might be interested in Malachi's prophecy that the Gentiles would bring pure offerings to the Lord and that they would fear Him as a great King (Malachi 1:11, 14). Malachi 3:1-3 may have been in Jesus' mind (Hiers 1971:87). Jesus' temple purification act is "to purify the sons of Levi" prophesied in Malachi 3:3 (Hiers 1971:87). Malachi's prophecy in 3:1 and following verses concerning temple renewal and reform is linked with the inauguration of a new era (Kummel 1957:118) that is, the launch of the messianic age - and so Malachi's promise is fulfilled in Jesus' temple act (Hiers 1971:231). Jesus' action in the temple is a symbolic-prophetic act foreshadowing divine judgment (Mal 3:5) as well as a fulfilment of Malachi 3:1-4. Regarding Luke 19:45-46, Jesus, being aware of Malachi 3:1-2 to consciously fulfil it, comes as Lord to his temple to purify like a refiner's fire (Nolland 1993: 935). It means that Jesus identified Himself as Malachi's הָזָדון and fulfilled his mission.

\subsubsection{Luke 19:47-21:38}

Even after his purification of the temple, Jesus' ministry in the temple continues. At both the beginning of this unit (19:47-20:1) and its conclusion (21:37-38), Luke presents Jesus' daily teaching in the temple. Jesus' purification of the temple is closely associated with his teaching, because his teaching is also the means by which the temple is purified (Dawsey 1984b:11). It may be said that Jesus' temple teaching is itself an eschatological activity (Dawsey 1987:227; 1984a:153-65).

In the OT, the Jerusalem temple was the central place for the administration and care of law. The priests preserved, interpreted, and transmitted the Law of Moses (Baltzer 1965:264). As in Jesus' temple cleansing act, his teaching ministry also indicates that He seizes the temple and exercises the office of king of Israel (Conzelmann 1970:196). Jesus' teaching ministry in the temple shows that the temple is his and, that He came to his temple to fulfil his mission. The lessons or instructions in Jesus' teaching ministry at the temple may reveal his mission to complete in regard to the temple. 
The confrontation scenes in Luke 19:45-20:47 may be viewed in the perspective of the confrontational framework provided by the Book of Malachi (Dawsey 1984b:227), as argued in the following statement:

Jesus' discourse to the disciples from the temple in Luke 21 is a prophecy about an impending judgment, which is both doom and salvation. It is very reminiscent of similar passages in the prophetic books of the OT. For example, the rich of Luke 21:1-4 are like the sons of Jacob mentioned in Malachi 3:6-10 who rob God by not bringing the full tithes into the storehouse. The widow of Luke 21:2-4, like the widow of Malachi 3:5, is counted among the righteous who will receive God's salvation (Mal 3:16-18) [Dawsey 1984a:157].

In the Gospel of Luke Jesus restores his temple instead of condemning it. The temple is proved as the crucial headquarters of God's saving work (Chance 1988:58). Therefore, Luke portrays the final temple scene as the central place for the gospel of salvation preached to the people (Chance 1988:59) and for true worship.

The Jewish leadership attacks the "Coming One" and challenges his authority. To the challenge of his opponents, Jesus defends his authority by referring to John's authority. If they accept that John's authority is from heaven, they should admit Jesus' divine authority. It is not accidental that He refers to John's authority to prove his divine authority regarding his visit to the temple. He implies that his authority is superior to John's and that John is his forerunner in accordance with Malachi 3:1. In brief, Luke points out that the authority of John and Jesus is from heaven. He consciously or unconsciously presents John as the preparer of the way of the Lord Jesus. In Malachi $3: 1$, the authority of the messenger of the Lord and of the covenant messenger is also from heaven.

In the parable of the tenants (20:9-19) Jesus identifies Himself as the beloved Son of God (20:13) and "Coming One." The parable implicitly shows two stages of divine visitation. One is the coming of the Son, but He is rejected. The other is the coming of God the Father. His visit brings horrific judgment against the wicked. Therefore, the day of God's visit is the "great and terrible day."

In the third incident (Luke 20:20-6), one significant phrase is the "way of God" ( $\tau \dot{\eta} v$

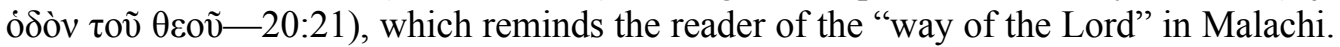
Jesus is the perfect teacher of the Word of God. He is the ideal teacher of the way of the Lord, whom the faithful teacher of the Law in Malachi 2:5-6 foreshadowed. Like the evil priests who turned from the ways of the law and by their teaching caused many to stumble, and who violated the covenant with Levi, the religious leaders in Jesus' day cause many to stumble. God denounced the priests of Malachi's day because they did not follow the ways of the Lord and they showed partiality in matters of the law

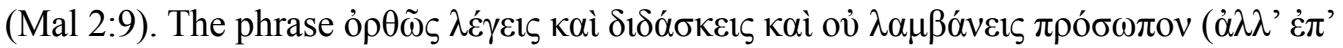

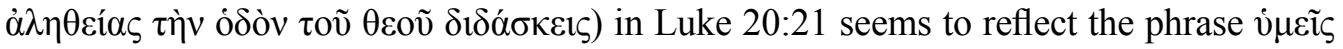

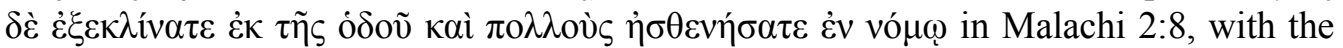

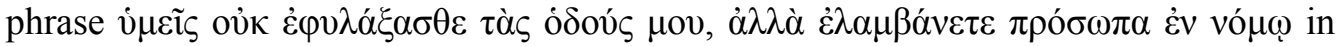
Malachi 2:9. Though both the OT and the NT show an antithetical parallel, the integrity 
and impartiality are required from the messengers of the Lord and emphasised in both biblical texts. To describe Jesus' impartiality Matthew and Mark use the Greek verb $\beta \lambda \varepsilon \dot{\pi} \omega$, but Luke uses $\lambda \alpha \mu \beta \alpha ́ v \omega$, which is found in the LXX' rendering of Malachi 2:9. Jesus is presented as the true messenger of the covenant promised in Malachi 3:1. Jesus exposes that the religious leaders distort the way of God and show partiality. The episode teaches that God's people should give acceptable offering to God.

The fourth incident Luke chooses in the scenes of Jesus' temple ministry is the discussion between Jesus and the Sadducees regarding the resurrection issue (Luke 20:27-40). The fathers are precious to God as his "treasured possession" and their names have been written in "a scroll of remembrance" (Mal 3:15-6). As God's children they will be spared for ever (cf. Mal 3:17; Luke 20:36).

In the fifth subunit which deals with Jesus' identity (Luke 20:41-4), Jesus cites Psalm 110:1 and points out in the verse that David calls Messiah his Lord. At the end of his life, David might have known that a great One would come to fulfill the promise made by God (Ross 1985:873). The psalm, therefore, seems to be connected with the Davidic Covenant in 2 Sam. 7:12-14. The "Lord" indicates YHWH (יהוה) and next, "my Lord" (אדוני) in Psalm 110:1 refers to the psalmist's Lord. The Hebrew word refers to God the Son/Messiah, has the same connotation in Malachi 3:1. The phrase "sit at my right hand" means not only being deposited at a place of honor or authority, but also the actual application of the authority as a mediator or co-ruler (Kraus 1986:112).

The sixth incident in the unit is Jesus' condemnation of the scribes (Luke 20:457). The Jewish religious leaders' evil treatment of the widows reminds the readers of the oppression of the widows in Malachi 3:5. At Malachi's time God announces his judgment on the wicked for their injustice. The prophecy will be finally fulfilled on the great and terrible Day of the Lord at the second coming of Christ. In this pericope Jesus also declares that the Jewish religious leaders will be punished, and that the scribes will meet with a greater punishment on the Judgment Day of the Lord.

The seventh subunit is Jesus' commendation of a widow (Luke 21:1-4). The Jewish leaders dishonor God, but the widow truly honours Him through her wholehearted commitment. The widow is a true God-fearer like those who feared the Lord and honour his name in Malachi 3:16. She is like the true worshippers whom the Lord sought at Malachi's time.

The eighth and final discourse in the unit is Jesus' instruction about Jerusalem's destruction and the end-time. Jesus' prophecy consists of the immediate future and the end-time of the world. Just as God wants Malachi's readers to be prepared for the Day of the Lord (Mal 4:5-6), Jesus encourages his readers to be ready to meet with his second coming.

To this point, this study has dealt with Jesus' third visit to the temple and its significance; there is a close link between Malachi's themes and the themes in Jesus' final temple ministry. In Luke 19:45-21:38 Jesus appears as the messenger of the covenant of Malachi 3:1ff (Dawsey 1984:158). 


\section{$4 \quad$ The Way of the Lord in Malachi 3:1 and the Way of the Lord in Luke}

One of the major themes in Malachi 3:1 is the way of the Lord. Malachi 3:1 is understood as a messianic prophecy and thus the theme should be dealt with. Luke seems to understand that the way of the Lord is "an actualization of God's purpose" (Navone 1970:190). Luke, in 3:4 and 7:27, makes literal reference to it. For example one can mention:

\subsection{Miscellaneous References to "way" in Luke}

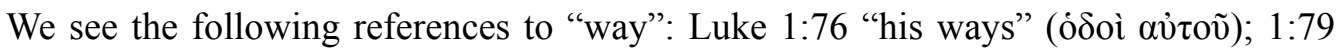

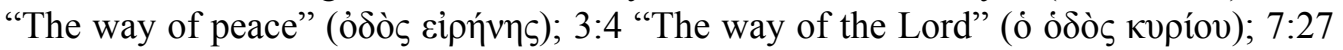

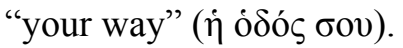

The Way of the Lord motif occurs in Luke 1:76 though the relevant noun has a plural form ("ways"). Luke 1:77 clearly reveals that the purpose ${ }^{10}$ of John's preparing the "way" is "to give his people the knowledge of salvation through the forgiveness

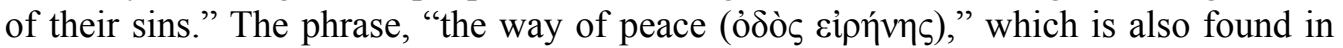
Zechariah's hymn, indicates the mission of Messiah who guides and leads the lost, those dwelling in darkness, into the way of God. The theme of the Lord's way is clearly found in association with the mission of John the Baptist in Luke because he is given the task of preparing the way of the Lord (cf. 1:76; 3:4-5; 7:27).

Luke depicts the way of the Lord as the way of peace, the gathering and feeding of his flock, and redemption (Van Zyl 2005:136-7). The theme, the way of the Lord, in Luke is fulfilment of Malachi 3:1, because Malachi's message is a prophecy.

\subsection{Jesus' Third Jerusalem Journey as the Way of the Lord $(9: 51-19: 46)^{11}$}

The second main part of the Gospel of Luke is Luke 9:51-19:46, which is the central section of the book. It is called "Lukan Travel Narrative" or "Jesus' Journey Narrative." The section consists of Jesus' third journey to Jerusalem and his entry into the Jerusalem temple. Though Jesus' journey to Jerusalem ${ }^{12}$ is one of the most characteristic aspects of Luke's Gospel, it is also the most puzzling section in the book (Matera 1993:57).

Luke seems to artificially create Jesus' final travel to Jerusalem (Brown 1979:244); the section is "a Lukan literary construction and not a historical report of Jesus' final journey to Jerusalem" (Matera 1993:59), which has "a theological concept."13 This journey represents a travel into the kingdom of God - that is, the way of the Lord and way of salvation (Borgman 2006:203-4), which is, "a stage along the way of the history of salvation" (Robinson 1960:61). The Travel Narrative section is more thematic and topical, rather than chronological and geographical (Bock 1996:1040). Luke visualises the continuity of the redemptive history as a way or a course (Robinson: 1960:61), and depicts Jesus' public ministry as a way (Robinson: 1960:62). In the Gospel of Luke, 
Christian discipleship is also a way (Fitzmyer 1985:241-2). Luke points the motif of the way out in more detail in the journey narrative (Van Zyl 2005:136-7). He again uses motif of the way in Luke 24, where the risen Jesus explains to his disciples on the way to Emmaus how to understand the messianic passages in the OT (Van Zyl 2005:136-7).

\section{Conclusion}

To this point, the study has shown that Malachi's eschatological figures' arrival motif appears in the Gospel of Luke. In a study such as this, one thing that needs to be taken into consideration is that "prophecy is not simply synonymous with prediction" (Frein 1994:22). Prophecy is not always identical with its fulfilment in a literal sense, but can be fulfilled in various ways. In other words, Luke cites and alludes to the themes or the motifs which occur in Malachi. There are some echoes of Malachi in Luke and thematic and literary parallels between Malachi and Luke (excluding Malachi and John's preaching). ${ }^{14}$

From the preface of the Gospel of Luke, Luke's literary structure contains Malachi's themes on the basis of prophecy-fulfilment pattern (Bock 1987). The picture of John/ Jesus is seen in light of the messenger of the Lord/the Lord in Malachi. ${ }^{15}$ Only Luke sees John's birth and his ministry as the preparation of the way of Jesus' birth and his ministry.

Luke emphasizes Jesus' visits to the temple, each with its own significance and purpose. Jesus' visit to the temple in Luke 2 foreshadows that $\mathrm{He}$ is the redeemer for his people. His second visit to the temple reveals that He is the Son of God who will fulfil God's salvation work. His final visit to the temple exposes Him as the enforcer of God's covenant, the one who purifies God's temple and his people, and also the judge of the wicked. The temple, Jesus' visit to His temple, and His symbolic act and intensive instructions in the temple in Luke must have been employed from Malachi. The Travel Narrative can be understood in the theological perspective of Malachi's motif of the way of the Lord and the sudden coming of to his temple and his role. Luke seems to see Jesus' travel itself as the way of the Lord, and as the journey to fulfil the way of the Lord at Jerusalem as well. The lessons given by Jesus in the Travel Narrative may be directly or indirectly linked with the motif of the way of the Lord. Especially the episodes or pericopae that verbally inform the reader that the travel is destined for Jerusalem are obviously associated with the motif of the way of the Lord or the ultimate purpose of Jesus' visit to the temple. The temple inclusio found in Luke 19:47 and 21:37-38 focuses on the significance of Jesus' teaching in the temple. It also implies that Luke sees Jesus' activity in the temple as the fulfilment of the prophecy of the visit of inaugurate a new temple (Watts 2007:312).

Malachi's theme, in which Exodus' messenger theme and Isaianic messenger theme are fused, is found in Luke. The "Coming One" motif on which Luke coherently places 
emphasis is a major theme in Malachi 3:1. Luke clearly manifests that Jesus is the "Coming One" as הָָאדון/the messenger of the covenant and that He is David's greater Son and Christ.

There are other allusions and parallels such as the theme of the Day of the Lord and "Covenant." Malachi contains several covenants, such as the Abrahamic Covenant, the Mosaic Covenant and the Davidic Covenant. Luke especially exposes the intimate relationship between Jesus and the covenants. He introduces Jesus as the Davidic messianic king. Luke presents Jesus and his parents as those who faithfully obey the Mosaic Law. Jesus purifies his people by fulfilling God's redemptive plan in the covenants. Jesus is the covenant enforcer, though He does not fully exercise his power and authority at his first coming.

Jesus' promise about the nations' repentance and forgiveness of sins (Luke 24:47) can be understood in the light of Malachi's prophecy regarding the nations' true worship in Malachi 1:11, 14. According to Malachi 3:4, the offerings of Judah and Jerusalem will be acceptable. Whereas the phrase "Judah and Jerusalem" represents Israel in Malachi 3:4 (cf. 2:11), "Jerusalem" in Luke indicates Israel. Luke 24 again presents Jesus as the redeemer of Jerusalem. ${ }^{17}$ The purification of the sons of Levi in Malachi 3:4 is fulfilled in the spiritual restoration of Jesus' disciples who return to the temple after Jesus' Ascension (Luke 24:52-3).

Luke's use of Malachi's prophecy contributes to the shaping of the contents and theology of his Gospel. By employing Malachi's prophecy, Luke especially confirms that Jesus is the coming Lord to his temple and covenant enforcer.

\section{NOTES}

1 The Book of Malachi, the last prophetic book of the Old Testament, prophesies that some figures will come and perform their tasks before the Day of the Lord comes, though there are different views about the number and interrelation of the characters. So the writer calls the coming of the figures, their functions and interrelated incidents "The Arrival Motif of Malachi's Eschatological Figures." This article can not go further into the details on account of limited space.

2 Cf. Mal 1:6 in Luke 6:46; Mal 1:11 in Luke 13:29; Mal 3:1 in Luke 1:17; Mal 3:12 in Luke 1:48; Mal 4:2 in Luke 1:78 and Mal 4:5 in Luke 9:8

3 This article consists of the development of previously observed facts and the argument of new knowledge.

4 The writer identifies the messenger of the covenant with הָָָדון in Mal 3:1 (Kaiser 1985:80-1).

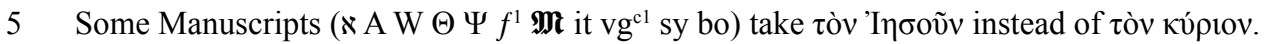

6 Even those who argue that Luke identifies Jesus as Elijah cannot deny the Elijah-John identification in Luke 7:27.

7 Cf. Figueras 1978:84-99. Law and Prophecy, represented by Moses and Elijah, as witnesses of Jesus' glory in his transfiguration favour a similar interpretation of Simeon and Anna's intervention at Jesus' first coming to the temple. 
8 cf. Nave 2002:17. The Greek word is "used as a term to express divinely ordained necessities. These necessities are unconditional."

9 The most widely accepted view takes the phrase, "in the (things) of my Father," as the Father's

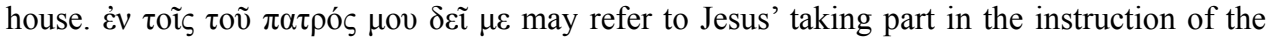
teachers in the temple. According to NEB (1843: The translator's note 1 "This verse involves an idiom that probably refers to the necessity of Jesus' being involved in the instruction of God, given what he is doing."

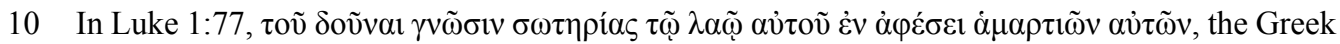
infinitive $\tau$ oṽ $\delta$ oṽval may express purpose or result, but here result may be a better interpretation.

11 Noël 2004. Filip Noël presents his comprehensive study concerning the Travel Narrative in the Gospel of Luke (9:51-19:28). He believes that the narrative ends at 19:28. This investigator, however, thinks that Jesus' journey ends with his entry into the temple.

12 Luke 9:51, 53, 57; 10:1, 38; 13:22, 33; 17:11; 18:31; 19:11, 28, 41, 45.

13 Kelly 1984:700; Fitzmyer 1970:241-2. All of Jesus' saving activities in His ministry may be

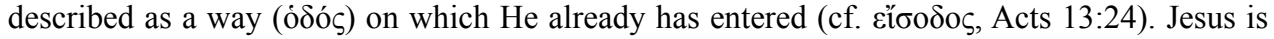
now moving along ( $\pi \circ \rho \varepsilon v ́ \varepsilon \sigma \theta \alpha \mathrm{l}$ ) and heading for his exodus in Jerusalem (Gospel according to Luke, 241-42).

14 This article mainly deals with some prophetic fulfilments in a literal or typological sense because space does not permit it.

15 The entire infancy narrative may be outlined as follows:

John - the forerunner of the Lord

1. Gabriel's announcement to Zechariah about John's birth (1:5-23)

2. Elizabeth's thanks and praise (1:24-25)

3. John's birth (1:57-65)

4. People's reaction to the birth (1:66)

5. The praise of Zechariah (1:67-79)

6. John's childhood (1:80)

Two mothers' meeting: Mary and Elizabeth (1:39-45) / Elizabeth and the baby in her womb acknowledge that the baby to be born of Mary is the Lord.

Jesus - the Lord

1. Gabriel's announcement to Mary about Jesus' birth (1:26-38)

2. Mary's thanks and praise (1:46-56)

3. Jesus' birth (2:1-16)

4. People's reaction to the birth (2:17-9)

5. The praise of angels and shepherds $(2: 8-14,20)$

6. Jesus' childhood (2:21-40)

16 Hill 1998:229-30; 278-9. Cf. Verhoef 1987:292.

17 Through the mouths of Jesus' disciples on the way to Emmaus, Luke again reminds his readers that Jesus' mission is to redeem Israel (Luke 24:20). In the last scene of Luke, Jerusalem is described as the centre of God's redemptive work for all the nations. The city is the place to which Jesus' disciples return and from which they begin to fulfil their mission (Luke 24:52). 


\section{BIBLIOGRAPHY}

Baltzer, K. 1965. The meaning of the temple in Lukan writings. HTS 58:264.

Blomberg, C. 1990. Interpreting the parables. Downers Grove: InterVarsity.

Bock, D. L. 1987. Proclamation from prophecy and pattern: Lucan Old Testament Christology. JSNTSup 12. Sheffield: JSOT.

Bock, D. L. 1996. Luke 1:1-9:50. Baker Exegetical Commentary on the NT. Grand Rapids: Baker.

Borgman, P. 2006. The way according to Luke: Hearing the whole story of Luke-Acts. Grand Rapids: Eerdmans.

Brooks, J. A. 1987. The influence of Malachi upon the New Testament. SwJT 30:31.

Brown, R. E. 1979. The birth of the Messiah: A commentary on the infancy narratives in Matthew and Luke. New York: Doubleday.

Chance, J. B. 1988. Jerusalem, the temple and the New Age in Luke-Acts. Macon, GA: Mercer University.

Conzelmann, H. 1970. History and theology in the passion narratives of the Synoptic Gospels. Int 24/2:165.

Conzelmann, H. 1960. The Theology of St Luke. Translated by G. Buswell. London: Faber \& Faber.

Danker, F. W. 1989. Luke. Proclamation Commentaries. 2nd ed. Philadelphia: Fortress.

Dawsey, J. M. 1987a. Confrontation in the temple. PRSt 14/3:153-65.

Dawsey, J. M. 1987b. Jesus' pilgrimage to Jerusalem. PRSt 14/3:227.

Dawsey, J. M. 1984. Confrontation in the temple: Luke 19:45-20:47. PRSt 11/2:158-9.

Ellis, E. 1974. The Gospel of Luke. NCB. London: Marshall, Morgan \& Scott.

Evans, C. A. 1989. Jesus' action in the temple: Cleansing or portent of destruction? CBQ 51:252.

Fay, R. C. 2006. The narrative function of the temple in Luke-Acts. TJ 27/2:258.

Figueras, P. 1978. Syméon et Anne, ou le témoignage de la loi et des prophètes. NovT 20:84-99.

Fitzmyer, J. A. 1970. The Gospel according to Luke I-IX: A new translation with introduction and commentary. AB 28. New York: Doubleday.

Fitzmyer, J. A. 1985. The Gospel according to Luke X-Xiv: A new translation with introduction and commentary. AB 28. New York: Doubleday.

Frein, B. C. 1994. Narrative predictions, Old Testament prophecies and Luke's sense of fulfillment. NTS 40:22.

Hiers, R. H. 1971. Purification of the temple: Preparation for the kingdom of God. JBL 90:82-90.

Hutcheon, C. R. 2000. "God is with us": The temple in Luke-Acts. SVTQ 44/1:47.

Kelly, J. G. 1984. Lucan Christology and the Jewish-Christian dialogue. JES 21/4:700.

Kilgallen, J. J. 1985. Luke 2, 41-50: Foreshadowing of Jesus, teacher. Biblica 66/4:557.

Kingsbury, J. D. 1991. Conflict in Luke: Jesus, authorities, disciples. Minneapolis: Fortress.

Kaiser, W. C., Jr. 1985. The uses of the Old Testament in the New. Chicago: Moody.

Kraus, H.-J. 1986. Theology of the Psalms. Translated by Keith Crim. Reprint 1979. Minneapolis: Augsburg.

Kummel, W. G. 1957. Promise and fulfillment: The eschatological message of Jesus. Translated by D. M. Barton. 3rd ed. SBT 23. Naperville, IL: Allenson. 
Laurentin, R. 1966. Jésus au temple: Mystère de paques et foi de Marie en Luc 2, 48-50 . Paris: Librairie Lecoffre.

Matera, F. J. 1993. Jesus' journey to Jerusalem (Luke 9:52-19:46): A conflict with Israel. JSNT 51:57.

Nave, Jr., G. D. 2002. The role and function of repentance in Luke-Acts, vol. 4. SBL and Academia Biblica. Atlanta: SBL.

Navone, J. 1970. Themes of St. Luke. Rome: Gregorian University.

Noël, F. 2004. The travel narrative in the Gospel of Luke: Interpretation of Lk 9,51-19,28, vol. 5. Collectanea Biblica Et Religiosa Antiqua. Brussel: Wetenschappelijk Comite voor Godsdienstgeschiedenis Koninklijke Vlaamse Academie van België voor Wetenschap.

Nolland, J. 1993. Luke 18:35-24:53. WBC 35c. Dallas: Word.

Nolland, J. 1989. Luke 1-9:20. WBC 35a. Dallas: Word.

O’Brien, J. M. 1990. Priest and Levite in Malachi, vol. 121. Atlanta: SBL Scholars Press.

Pao, D. W. and E. J. Schnabel. 2007. Luke, in Commentary on the New Testament use of the Old Testament, edited by G. K. Beale and D. A. Carson, 276f. Grand Rapids: Baker Academic.

Ross, A. P. 1985. Psalms, in Bible Knowledge Commentary: Old Testament, edited by J. F. Walvoord and R. B. Zuck, 873f. Vol. 1 of Bible Knowledge Commentary: An Exposition of the Scriptures by Dallas Seminary Faculty. Wheaton: Victor.

Snodgrass, $\mathrm{K}$. The use of the Old Testament in the New, in The right doctrine from the wrong text? Essays on the use of the Old Testament in the New, edited by G. K. Beale, 38f. Grand Rapids: Baker Academic, 1994.

Steyn, G. J. 2005. Soteriological perspectives in Luke's Gospel, in Salvation in the New Testament: Perspectives on soteriology, edited by J. G. van der Watt, 213-46. NovTSup 121. Leiden: Brill.

Van Zyl, H. C. 2005. The soteriology of Acts: Restoration to Life, in Salvation in the New Testament: Perspectives on soteriology, edited by J. G. van der Watt, 133-160. NovTSup 121. Leiden: Brill.

Van der Waal, C. 1973. The temple in the Gospel according to Luke. Neot 7:53-54.

Verhoef, P. A. 1987. The Books of Haggai and Malachi. NICOT. Grand Rapids: Eerdmans.

Watts, R. E. 2007. The Lord's house and David's lord: The Psalms and Mark's perspective on Jesus and the temple. BibInt 15:312. 